Recebido em 04/2019. Aceito para publicação em 09/2019.

\title{
NO LUGAR PERIURBANO E ATRAVÉS DELE: ANÁLISE DA ACESSIBILIDADE SOCIAL NA REGIÃO NOROESTE DO MUNICÍPIO DE JACAREÍ, SP, BRASIL
}

\section{IN THE PERI-URBAN PLACE AND THROUGH IT: ANALYSIS OF SOCIAL ACCESSIBILITY IN THE NORTHWEST REGION OF THE MUNICIPALITY OF JACAREÍ, STATE OF SÃO PAULO, BRAZIL}

André Luiz de Toledo 1

Adriane Aparecida Moreira de Souza²

Cilene Gomes ${ }^{3}$

\begin{abstract}
Resumo: A acessibilidade dos moradores da Região do Parateí do Meio aos benefícios da vida social urbana é o objeto principal de análise desse artigo para o entendimento do lugar periurbano. A metodologia de pesquisa utilizada orientou-se para a realização de um estudo de caso e consiste em uma triangulação de métodos gerais e técnicas relacionando as fases exploratórias, trabalho de campo e análise documental. Além disso, incluiu levantamento fotográfico e de coordenadas geográficas para a construção de um banco de dados georreferenciados e mapeamentos. Partindo da contextualização e circunstância da localização da área de estudo, no município de Jacareí, SP, os resultados específicos do artigo incluem uma leitura histórica da organização territorial em relação ao sistema viário e os eixos de urbanização e desenvolvimento; o apontamento dos cerceamentos de estradas locais, um panorama das paisagens dos bairros da Região e dados sobre o potencial de acessibilidade física e social dos moradores. A composição da imagem da periurbanidade do lugar conduz às considerações finais a respeito de questões do planejamento territorial ligadas, sobretudo, à necessidade de um pensamento mais compromissado com as transformações sociais e territoriais, estabelecido com base nos direitos de cidadania.
\end{abstract}

Palavras-chave: Circulação; acessibilidade; periurbanidade; lugar; cidadania.

Abstract: The accessibility of the residents of the Region of Paratei do Meio to the benefits of urban social life is the main object of analysis of this article to understand the peri-urban place. The research methodology employed was oriented in a way to perform a case study and consists in a triangulation of general methods and techniques correlating the exploratory phases, field work and documental analysis. Furthermore, it included a survey on photographic records and geographic coordinates for the construction of a bank of georeferenced data and mappings. Based on the context and circumstances of the location of the study area in the city of Jacarei, the article explains the establishment of the place, by the organization of landscapes and different spaces; the problem of enclosure to local circulation; and the effective conditions of social accessibility including relational dynamics among different locations. The image composition of place periurbanity brings final considerations about the concept of social accessibility and issues of territorial planning linked mainly to the need for a more committed thought to social and territorial transformations, established in the rights of citizenship.

Keywords: Circulation; accessibility; peri-urbanity; place, citizenship.

\section{INTRODUÇÂO}

Vive-se há tempos no Brasil uma crise em que a insustentabilidade socioespacial

\footnotetext{
1 Mestre em Planejamento Urbano e Regional, Universidade do Vale do Paraíba, Brasil. E-mail: altoledo@univap.br.

2 Docente do Programa de Pós-Graduação em Planejamento Urbano e Regional/Universidade do Vale do Paraíba, Brasil. E-mail: adriane@univap.br.

${ }^{3}$ Docente do Programa de Pós-Graduação em Planejamento Urbano e Regional/Universidade do Vale do Paraíba, Brasil. E-mail: cilenegs@univap.br.
} 
fundada nas desigualdades torna-se aguda e persistente, induzindo, em todo lugar, a diversas manifestações sociais. No campo da produção do conhecimento, tal condição da sociedade contemporânea instiga à elaboração de trabalhos de análise e investigação cada vez mais compromissados com o interesse social.

A força desse posicionamento teórico-metodológico poderá realimentar atitudes e formulações destinadas à aspiração por um novo período da história e projeto social construído coletivamente, cuja centralidade deve estar efetivamente na restauração da dignidade humana e da sociedade em seu todo e, por conseguinte, do lugar em que se vive e, não mais exclusivamente, na lógica especulativa do capital.

Logo, por necessidade e urgência, uma completa inversão da visão da realidade deve ser efetivada, caso se deseje de fato colaborar para estabelecer as bases da construção do espaço humano de modo que este se torne de todos realmente - o lugar da libertação do homem das amarras que o enredam na alienação cultural e violência, subjugação política, nas segregações e intolerâncias do cotidiano e na ilusão da felicidade pelo consumo.

As mobilizações sociais e políticas a que se assiste nos últimos anos no País constituem a evidência de que o crescente número populacional urbano poderá criar novas forças de resistência ao que se torna humana e socialmente insustentável.

A renovação e os avanços do entendimento dos processos sociais e das práticas de planejamento, podem, segundo Santos (2000, p. 147), contribuir com a dissolução de ideologias perversas e inserir o homem "no centro das preocupações do mundo, como um dado filosófico e como uma inspiração para as ações".

Daí reconsiderar o fato contemporâneo de ser nossa relação com o mundo uma relação local-global, centrada no lugar e intermediada pelo lugar e/ou pelos nexos do global, do mundo globalizado - o lugar da vida em comum constituindo a dimensão do planeta ao nosso alcance, o quadro de referência de nossa consciência e vivência do que é o mundo hoje. No recorte de estudo da atual Região Metropolitana do Vale do Paraíba e Litoral Norte (RMVPLN), esta perspectiva, de análise das relações entre o todo social e suas partes, tem sido estabelecida como direção teórico-metodológica segura para o necessário cotejamento entre realidade, teoria e ação planejada. No presente artigo, uma pequena amostra do referido processo de trabalho será explicitada a partir de um retrato do município de Jacareí (SP), em suas conexões com o espaço urbano-regional do Vale do Paraíba Paulista e com o lugar periurbano que se descortina em sua Região Noroeste, também conhecida como região do Parateí do Meio.

Para além das dinâmicas relacionais e organização das paisagens estritamente locais, busca-se ampliar o discernimento dos nexos globais esclarecedores da realidade do lugar, enquanto elo de um só espaço e sociedade em transformação. Para isso, a opção metodológica sugerida por Magnani (2002) - que combina a visão "de fora e de longe" com a visão "de perto e de dentro" do lugar em estudo -, tornou-se primordial. 
Nesse sentido, de forma complementar ao conhecimento fundado em informações secundárias sobre o lugar, os moradores e os frequentadores da Região do Parateí do Meio tornaram-se o centro de observações e interlocuções que possibilitaram evidenciar formas de apropriação e de atribuição de valores ou significados ao lugar.

Nesse artigo, o problema da acessibilidade constituiu o foco de uma correlação entre a dinâmica da circulação local e o acesso efetivo dos moradores ao espaço social urbano, possibilitando reflexões sobre as demandas desatendidas e os desacertos do modelo hegemônico excludente de desenvolvimento e planejamento.

O artigo encontra-se organizado em duas seções: na primeira, o contexto histórico e a circunstância da localização periurbana do território em estudo são referidos pela situação do sistema viário regional e dos nexos sociais mais gerais implicados na transformação deste território; e na segunda, os aspectos físicos e de infraestrutura urbana que marcam a Região do Parateí do Meio são balizados pelas condições de acessibilidade física e social e pelas dinâmicas relacionais que as sustêm, para, finalmente, ressaltar a questão da política pública de caráter territorial que surge pelo impasse estabelecido entre as atuais diretrizes do empresariamento de grandes projetos urbanos e a ineficiência coletiva na busca de efetiva garantia dos direitos de cidadania.

\section{A CAMINHO DO LUGAR: contexto e circunstância da localização}

O sistema viário regional é o elemento primordial para entender a acessibilidade dos moradores do Parateí do Meio. A relação entre vias e territórios adjacentes estabelece um quadro amplo para notar a periurbanidade dessa localidade, se entendermos o conceito de periurbanidade associado à condição de um espaço fronteiriço e conflituoso, conforme sugestão de Randolph e Southern (2011). Pressupõese nesta pesquisa que a relação entre a história do povoamento e a urbanização do Vale do Rio Paraíba expliquem a particular circunstância de localização dos moradores em seu preciso lugar de vida, possibilitando um entendimento desse lugar, em seu atual contexto de relações limítrofes com o mundo urbano-regional e sua condição de relativo isolamento socioespacial.

De fato, na Região do Vale do Paraíba, o sistema de caminhos construído ao longo do tempo condicionou os processos de povoamento, urbanização e desenvolvimento regional. Os relatos de Saint-Hilaire (1822 apud SAPUCAHY, 1998) e os estudos de Muller (1969, p. 20) elucidam o papel da circulação na organização do espaço regional dos primeiros séculos ao promover os fluxos de interligação de longo alcance entre diferentes regiões dos estados de São Paulo, Rio de Janeiro e Minas Gerais.

Esse efeito organizador do espaço regional pelo sistema viário e de fluxos se evidencia com mais nitidez com o processo de industrialização que, na primeira metade do século $\mathrm{XX}$, impulsiona o aumento populacional, principalmente nos municípios 
localizados no Médio Vale do Paraíba. Neste período, verifica-se a linearidade da organização do espaço regional reforçada pelas ocupações industriais e a implantação de bairros residenciais em áreas próximas ao Rio Paraíba do Sul e, principalmente, em áreas paralelas à Rodovia Presidente Dutra, que, ao ser inaugurada em 1950, se tornou o principal vetor de escoamento de mercadorias e de deslocamento a partir da Região em direção às cidades de São Paulo e Rio de Janeiro.

Inspirada pela ideologia da modernização nacional e do planejamento estatal, essa urbanização ao redor do eixo Dutra acentua-se cada vez mais até os anos 70 , com o aumento demográfico e o redimensionamento funcional e morfológico dos centros urbanos aí localizados, afetando negativamente o desenvolvimento das cidades mais distantes deste eixo principal.

Entende-se assim a hierarquização dos centros urbanos pelo sistema de circulação regional e a força de regionalização que os sistemas de engenharia tendem a exercer, sobretudo em tempos de globalização, quando a integração territorial adquire outro significado com a incorporação de novas tecnologias nas dinâmicas econômicas e sociais. Analisado por Silva Neto (2002) trata-se do espraiamento do "fenômeno técnico-econômico", criando territórios do novo mercado ao longo da Dutra e nas imediações da Rodovia Carvalho Pinto.

Entre outras cidades que marcaram a história do espaço regional do Vale do Paraíba Paulista destaca-se Jacareí, uma cidade de porte médio, localizada nas imediações de duas importantes rodovias regionais - Rodovia Presidente Dutra e Rodovia Carvalho Pinto -, de traçado longitudinal e com expansões fragmentárias do tecido urbano visíveis em diversos alcances do território municipal inclusive no entroncamento destas duas rodovias com a Rodovia Dom Pedro I e, no entorno desta, em direção ao município de Igaratá. É justamente por esta confluência da circulação rodoviária que se pode adentrar a Região Noroeste do município, a área em estudo (figura 1).

Antes mesmo da existência das Rodovias Presidente Dutra e Dom Pedro I, já era possível chegar a essa porção Noroeste do território municipal pela antiga Estrada Santa Isabel-Jacareí, cujo papel histórico e geográfico foi destacado por Ab'Saber (1951) e pelo Consórcio de Desenvolvimento Integrado do Vale do Paraíba, (CODIVAP, 1972), em sua relação modesta com o desenvolvimento industrial, com o processo de polarização da cidade de São Paulo e as interligações com Arujá e Jacareí, e em sua posição secundária no sistema viário regional.

Em 1952, na Região Noroeste do município de Jacareí teve início o funcionamento da Variante Ferroviária do Parateí. A implantação deste trecho ferroviário promoveu certo desenvolvimento nessa mesma Região, ao receber diversos investimentos, em especial do setor imobiliário, voltado à criação de loteamentos e comercialização de terras (AB'SABER, 1951). Contudo, a ferrovia também veio interromper o curso da Estrada Santa Isabel-Jacareí, reforçando ainda mais sua condição marginal, dada a 
indiferença do poder público quanto à fragmentação da estrada.

A partir dos anos 50 do século $X X$, transformações sucessivas do espaço regional do Vale do Paraíba associaram-se à macrourbanização do entorno da Rodovia Presidente Dutra. Com as estratégias do poder público federal e estadual inspiradas no modelo de desenvolvimento industrial e científico-tecnológico e no princípio da seletividade espacial (SANTOS; SILVEIRA, 2001) -, na escolha das localizações mais vantajosas, a circunstância periurbana da Região do Parateí do Meio tornou-se ainda mais legível.

Figura 1 - Localização de Jacareí e da área de estudo

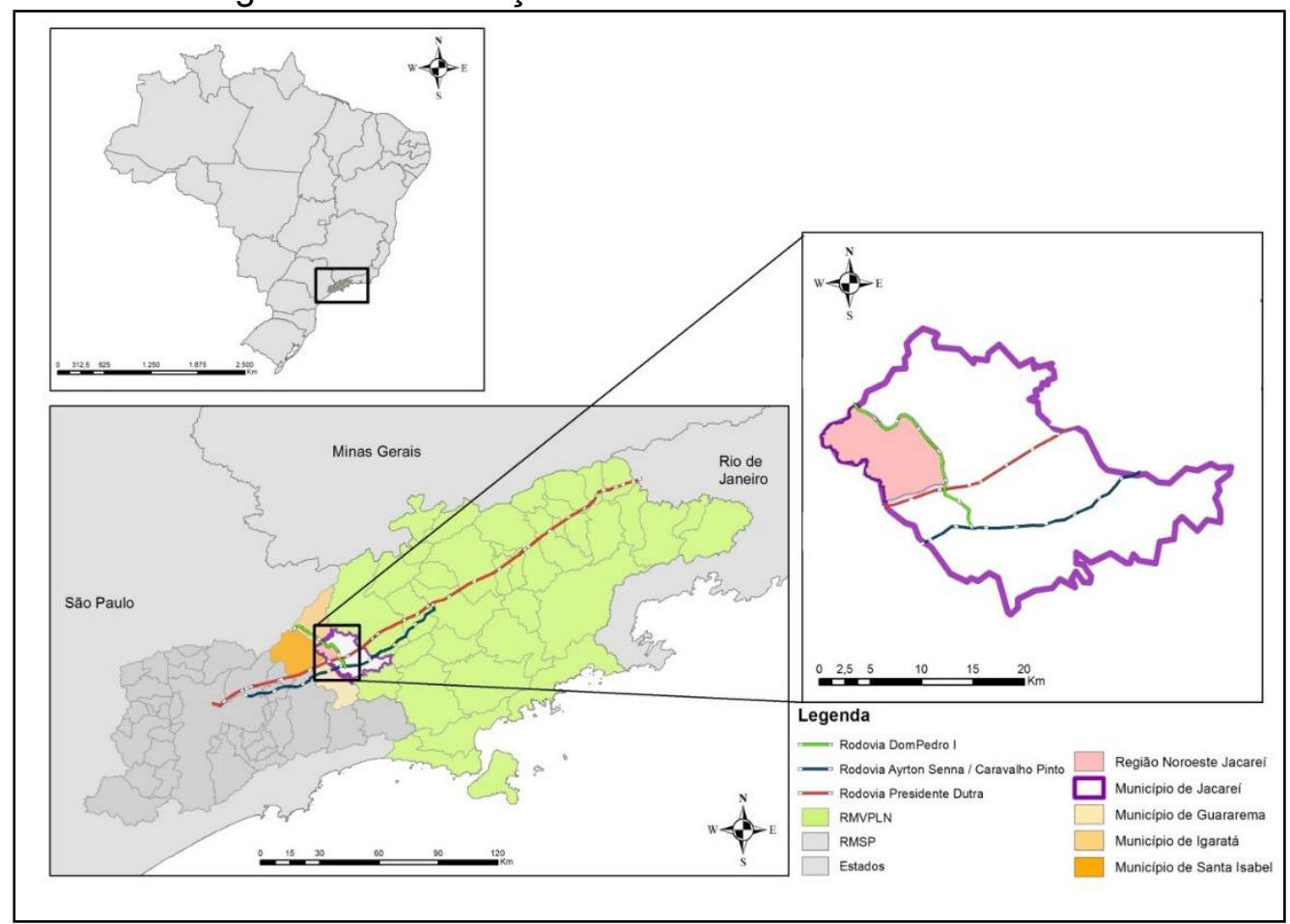

Fonte: IBGE, 2010. Elaboração de Daniel José de Andrade.

Ao Sul, A localização fronteiriça da Região do Parateí do Meio se exprime, em sua porção sul, pela contiguidade ao mundo urbano em razão do acesso relativamente fácil a duas importantes rodovias estaduais e pela inserção de parte de seu território na macrozona de interesse industrial (figura 2), definida pelo Plano Diretor do município de Jacareí.

Além disso, como mostra a figura 3, a periurbanidade da Região do Parateí do Meio também pode ser entendida pelo fato de não se constituir como área demarcada para o ordenamento da urbanização, sendo a área 2 a prioritária para a futura expansão urbana do município, fundada, como registra o referido Plano, na busca da sustentabilidade do crescimento econômico pela atração de grandes empreendimentos industriais e imobiliários.

Com o planejamento voltado exclusivamente à expansão urbana, a periurbanidade do Parateí do Meio significa, no mínimo, sua condição de lugar de 
reserva para futuros investimentos urbanos. Essa condição periurbana pode ser reforçada, ainda, pela implantação relativamente próxima do polo automotivo de Jacareí, ancorado pela montadora chinesa Chery, em funcionamento desde 2013 (ALVES, 2015). Esse é apenas um indicador do novo ritmo de transformações da referida área de expansão a partir da presença de um agente econômico global.

Figura 2 - Macrozoneamento de Jacareí, SP.

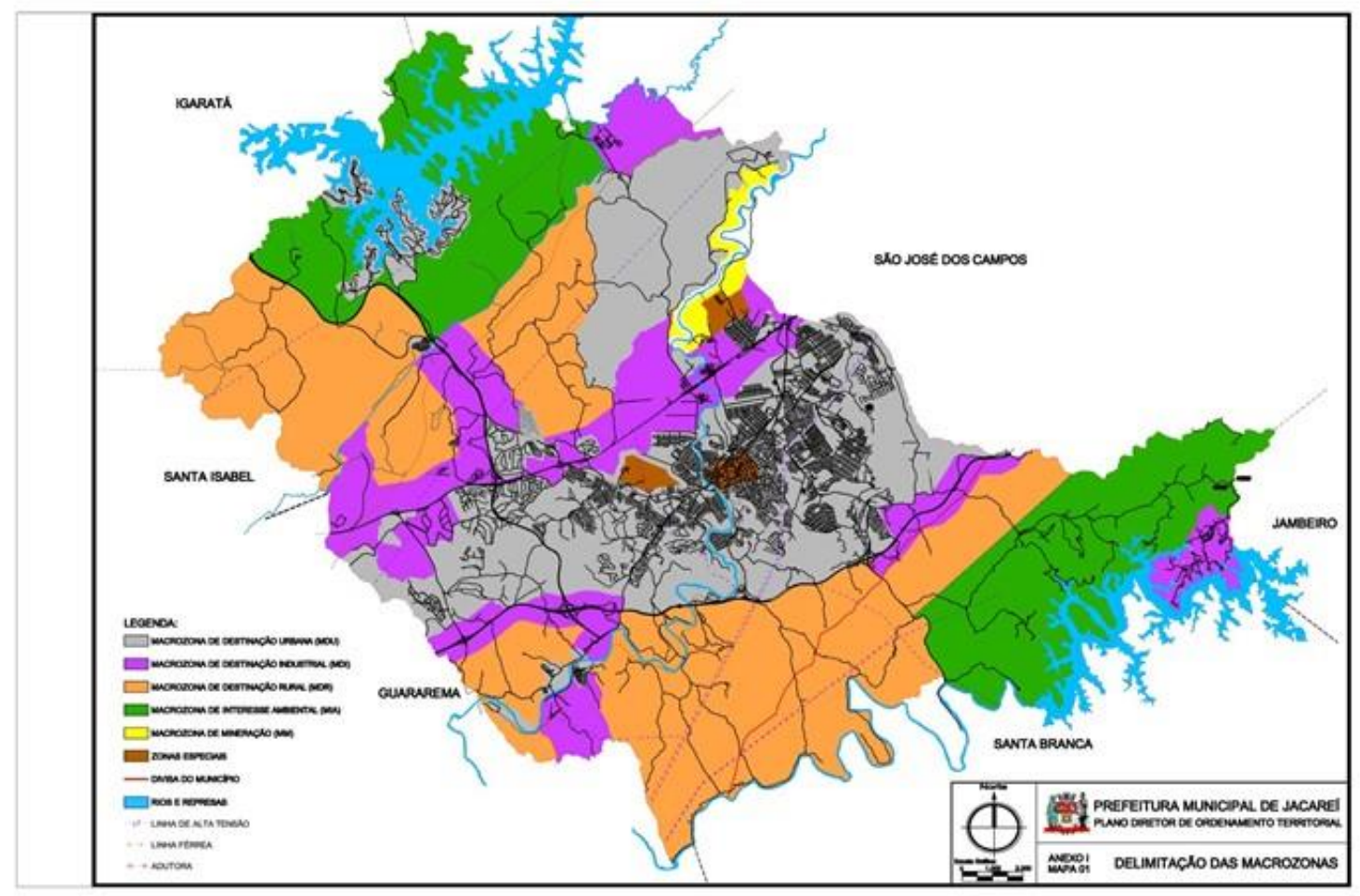

Fonte: Jacareí, 2012.

Elaborado por Daniel José de Andrade. 
Figura 3 - Territórios da expansão urbana demarcados no Plano Diretor do Município de Jacareí, SP.

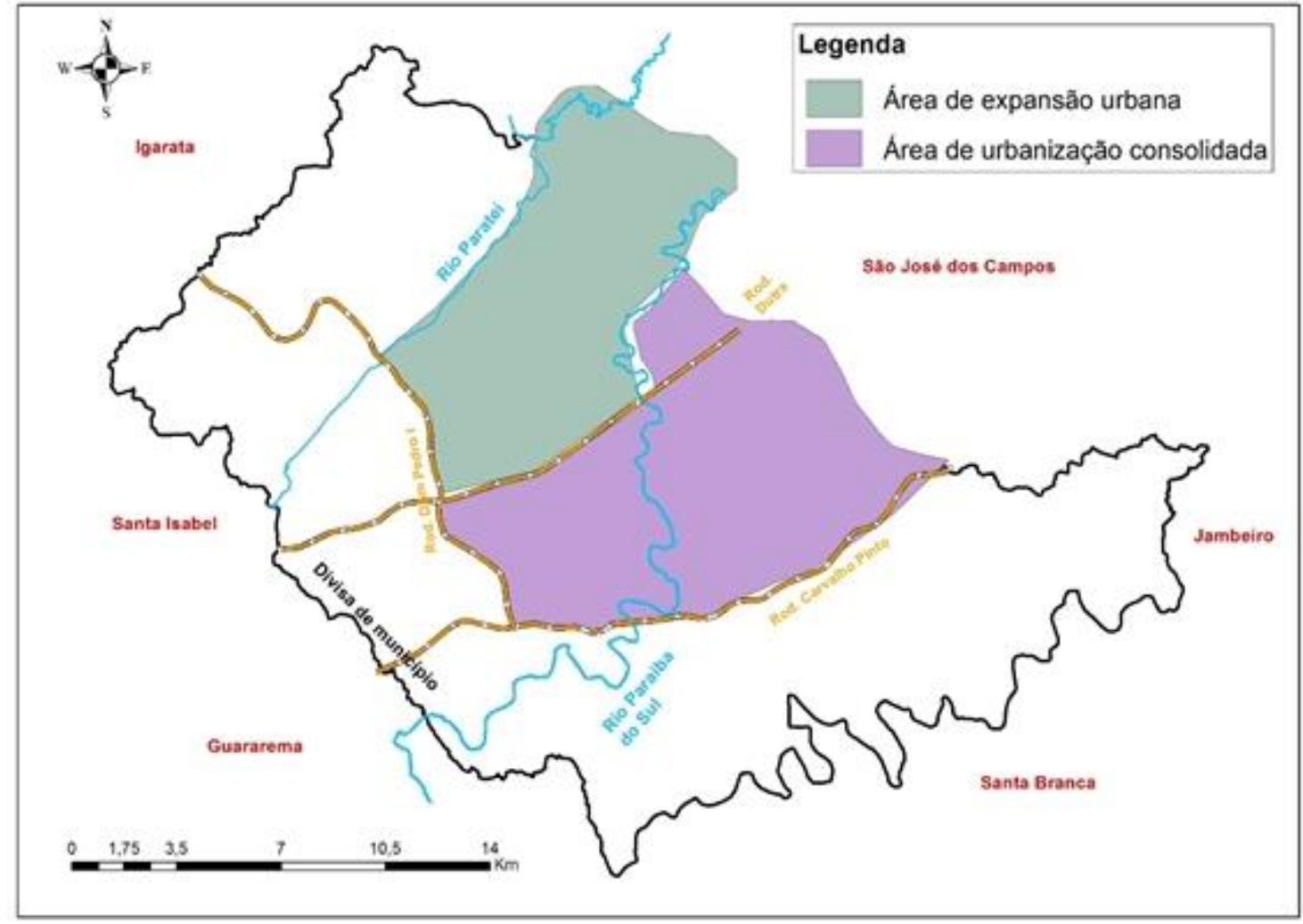

Fonte: Jacareí, 2012.

A periurbanidade da região denota, sobretudo, o descaso relativo à realidade das populações dispersas em meio rural que, ignoradas no plano diretor, mantêm-se à margem da atenção do poder público, permanecendo socialmente isoladas e violadas em seus direitos constitucionais.

\section{NO LUGAR E DE PASSAGEM POR ELE: a região do Parateí do Meio}

A Região do Parateí do Meio foi escolhida para estudo a partir da identificação de alguns obstáculos à livre circulação em um de seus bairros: o Figueira. Definiu-se a pesquisa com o propósito de se percorrer as estradas rurais dessa localidade (o Figueira) e imediações (no alcance de toda a Região do Parateí do Meio), observando, mapeando e relatando suas reais condições de circulação, para analisar as relações entre circulação e acessibilidade social e subsidiar uma discussão sobre o planejamento territorial - mais especificamente, o Plano Diretor do Município de Jacareí -, as relações urbano-rurais e a cidadania.

\subsection{O cerceamento das estradas locais}

Neste estudo pretende-se avaliar em que medida os cerceamentos das estradas limitam ou não a acessibilidade dos moradores aos benefícios da vida social urbana. Dados e informações são combinados aos resultados obtidos in loco, por meio de 
leituras da paisagem e entrevistas com trinta e sete moradores e outros agentes. A fase inicial exploratória incluiu visitas ao Bairro da Figueira e adjacências, a realização de percursos de bicicleta, conversas informais, registros fotográficos e marcações de locais representativos do cerceamento com o uso do GPS.

Avaliando, inicialmente, a Estrada Velha Santa Isabel-Jacareí, dois cerceamentos foram identificados: a ferrovia e uma pinguela sobre o Rio Parateí. Até hoje essa precária passagem substitui a ponte destruída nos anos 1980 por uma enchente, que ocasionou desbarrancamento das margens e abalo da estrutura da ponte. Assim, a travessia arriscada do rio é hoje possível apenas a certos pedestres e o tráfego até Santa Isabel é praticamente irrealizável (figura 4).

Figura 4 - Precárias condições de circulação.

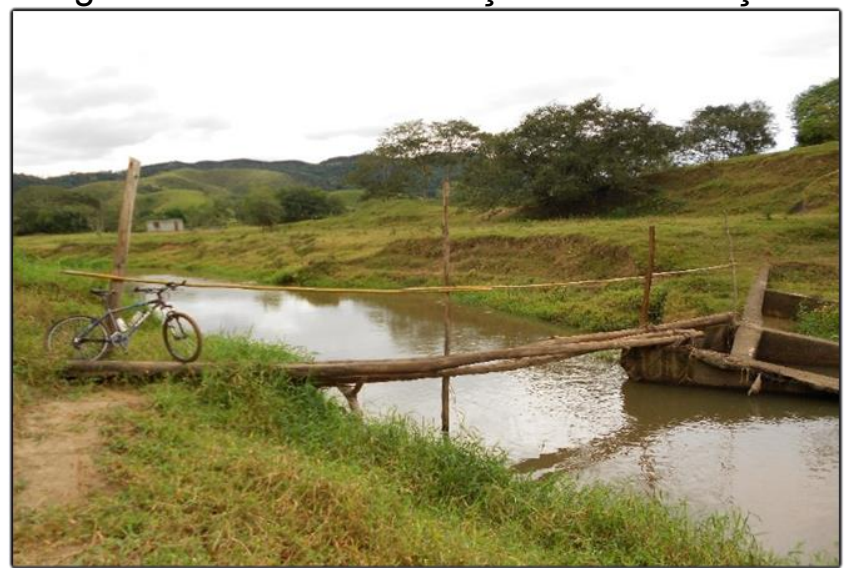

Fonte: Toledo, 2013a.

Após a travessia do rio, distante um quilômetro de uma "pinguela"4 - termo popular que se refere a uma ponte rústica, geralmente produzida com alguns troncos de madeira, nova interrupção da circulação pela Estrada Velha é encontrada, em razão de outra ponte ter sido arrastada pela água transbordada da represa de Jaguarí, município de Igaratá, devido à enchente de janeiro de 2010.

Outra limitação dessa estrada é o Condomínio Pedra Branca, de chácaras comercializadas clandestinamente. No local, a estrada deixa de existir na paisagem, com desvio da circulação por uma trilha difícil, possível apenas para pedestres, até que novamente se encontre o antigo curso da Estrada (figura 5).

Durante a realização dos percursos, descobriu-se um caminho alternativo de exatos seis quilômetros, criado pela população local, para cruzar o Rio Parateí sem uso da referida "pinguela". Nesse trajeto foi preciso passar por duas cercas e outra ponte precária capaz de suportar apenas a passagem de veículos leves, como bicicletas.

\footnotetext{
${ }^{4}$ Ponte rústica e estreita feita com alguns troncos ou tábuas.
} 
Figura 5 - Estrada interrompida por Condomínio.

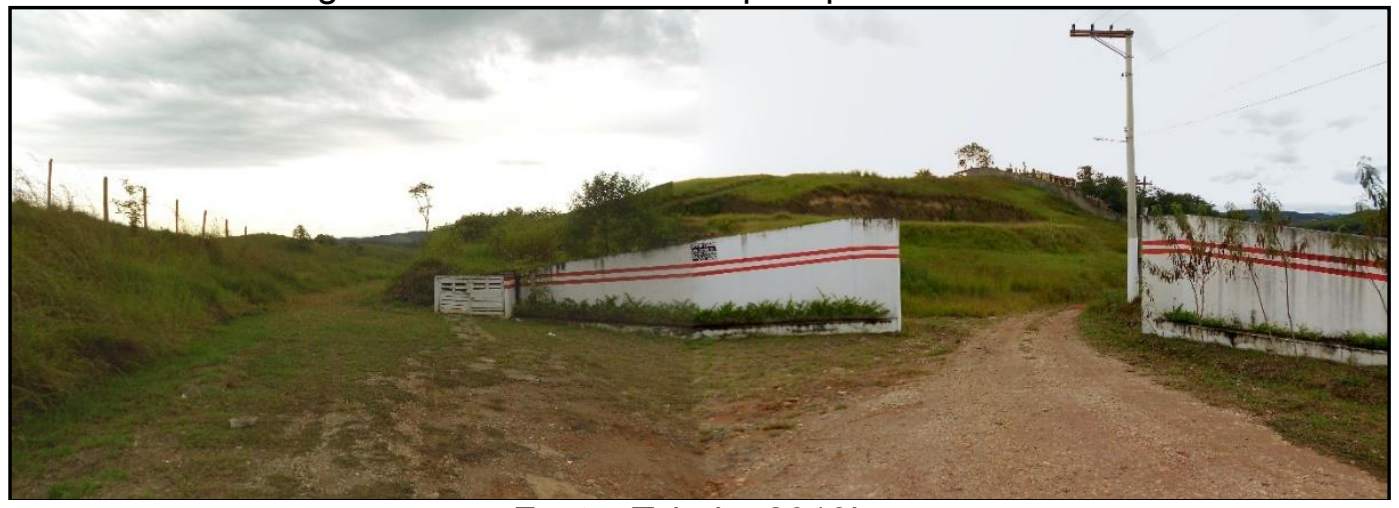

Fonte: Toledo, 2013b.

À parte essas condições impeditivas da circulação local, impostas pelo problema crônico da Estrada Santa Isabel-Jacareí, outros trechos viários nas proximidades do Bairro da Figueira possibilitam a circulação da população moradora e, além dela, de ciclistas a passeio e outros transeuntes. Os apontamentos evidenciam que na ausência do poder público, as populações e outros passantes resolvem da forma que podem o problema da circulação, na maioria das vezes, com limitações, de forma precária e dificultosa, atendendo a poucos segmentos da população local. Cercas, vegetação cerrada, trilho da ferrovia, pinguelas e as próprias ruínas de antigas pontes são exemplos de obstáculos que, quando transpostos, oferecem riscos aos pedestres.

Essa acessibilidade física deficiente torna-se ainda mais acentuada pela limitação do serviço de transporte público, oferecido ao atendimento das necessidades de deslocamento da população local para o trabalho, ao acesso a bens e serviços e à vida de relações sociais necessários à sobrevivência.

Outro agravante à circulação local, resulta da própria localização da Região Noroeste de Jacareí, assentada ao lado de grandes rodovias: Rodovia Presidente Dutra e Rodovia Dom Pedro I. Ao estabelecerem direções, velocidades e acessos favoráveis aos lugares da Região Metropolitana (e, mesmo, do estado paulista) mais integrados economicamente, tais vias expressas funcionam como entraves aos deslocamentos e à vida dos moradores locais. Relativamente isolada pelos cerceamentos à livre circulação local e pela precariedade do meio rural, a Região Noroeste torna-se um verdadeiro "beco sem saída" pela condição de vulnerabilidade vivida pelos moradores. O carro incendiado (figura 6), provavelmente furtado, simboliza a violência que ocorre nos trechos de estradas interrompidas, que não levam a nenhum lugar. Nessa circunstância de acuamento pela estrutura social e urbana do município, até mesmo o acesso da população local às próprias moradias não é algo fácil ou tranquilo.

Enquanto o poder público está ausente, os cerceamentos dividem a opinião dos moradores. Alguns consideram que a pouca circulação de pessoas e veículos favorece a manutenção do sossego nos bairros, tantas vezes quebrado por ocorrências indesejáveis de violência. Outros veem a circulação de mais pessoas como algo positivo para que todos conheçam bem o lugar e para o seu progresso, pois, sem ela, diz um 
entrevistado, "muita coisa deixou de funcionar". Este foi o caso da antiga escola e capela Santa Cruz do Matão que, após a enchente e queda da ponte, foram desativadas e hoje são ruínas (figura 7).

Figura 6 - Estrada da Figueira.

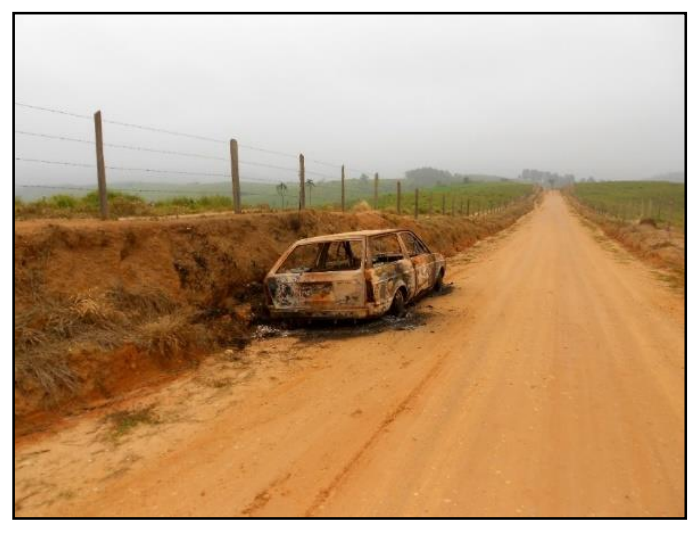

Fonte: Toledo, 2014a.
Figura 7 - Ruínas - escola e capela.

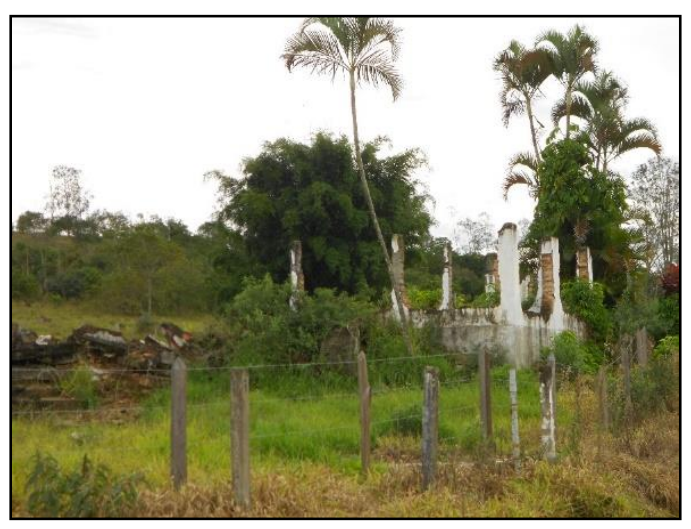

Fonte: Toledo, 2014b.

\subsection{Organização das paisagens e espaços diferenciados}

Com os levantamentos em campo, a compreensão da organização das paisagens do Parateí do Meio, compondo espaços diferenciados, tornou-se possível. Na figura 8, tem-se uma representação do lugar, situando os núcleos da vida social na região do Parateí do Meio, incluindo os bairros da Figueira, o Jardim Santana, o Jamic e o Brotas.

O Bairro da Figueira foi porta de entrada na região do Parateí do Meio. Cortado pelo Rio Parateí, o Bairro localiza-se na divisa das bacias dos Rios Tietê e Paraíba do Sul e dos municípios de Guararema e Santa Isabel. De acordo com Kanazawa (2008) em meados do século XX, o Bairro recebe grande quantidade de migrantes japoneses, mas, como no bairro vizinho do Jamic, nos anos 90 seus descendentes deixam o Bairro da Figueira, vendem propriedades e mudam de residência para o centro do município de Jacareí, tornando-se revendedores dos produtos de uma companhia estadual de abastecimento hortícola nas feiras livres desta cidade.

O Bairro é cortado pela Estrada Santa Isabel-Jacareí, com acesso pela Rodovia Presidente Dutra. Por outro lado, da Rodovia Dom Pedro I chega-se ao Bairro pela antiga estrada de interligação com outras regiões do Estado de São Paulo, e pelas Estradas Jamic e Hondo-Japão, por onde os veículos do transporte público também circulam.

Muitos dos atuais moradores viveram somente neste lugar. Nessas duas últimas décadas novos moradores passaram a habitar o Figueira e uma área vizinha correspondente ao bairro Jamic: são os moradores de fim de semana, residentes em chácaras ou frequentadores de haras - outros agentes não locais, oriundos de outros lugares, provavelmente dos arredores metropolitanos de São Paulo, estabelecendo 
dinâmicas relacionais no local com outras racionalidades, valores e hábitos.

Figura 8 - Mapa dos bairros da Região do Parateí do Meio.

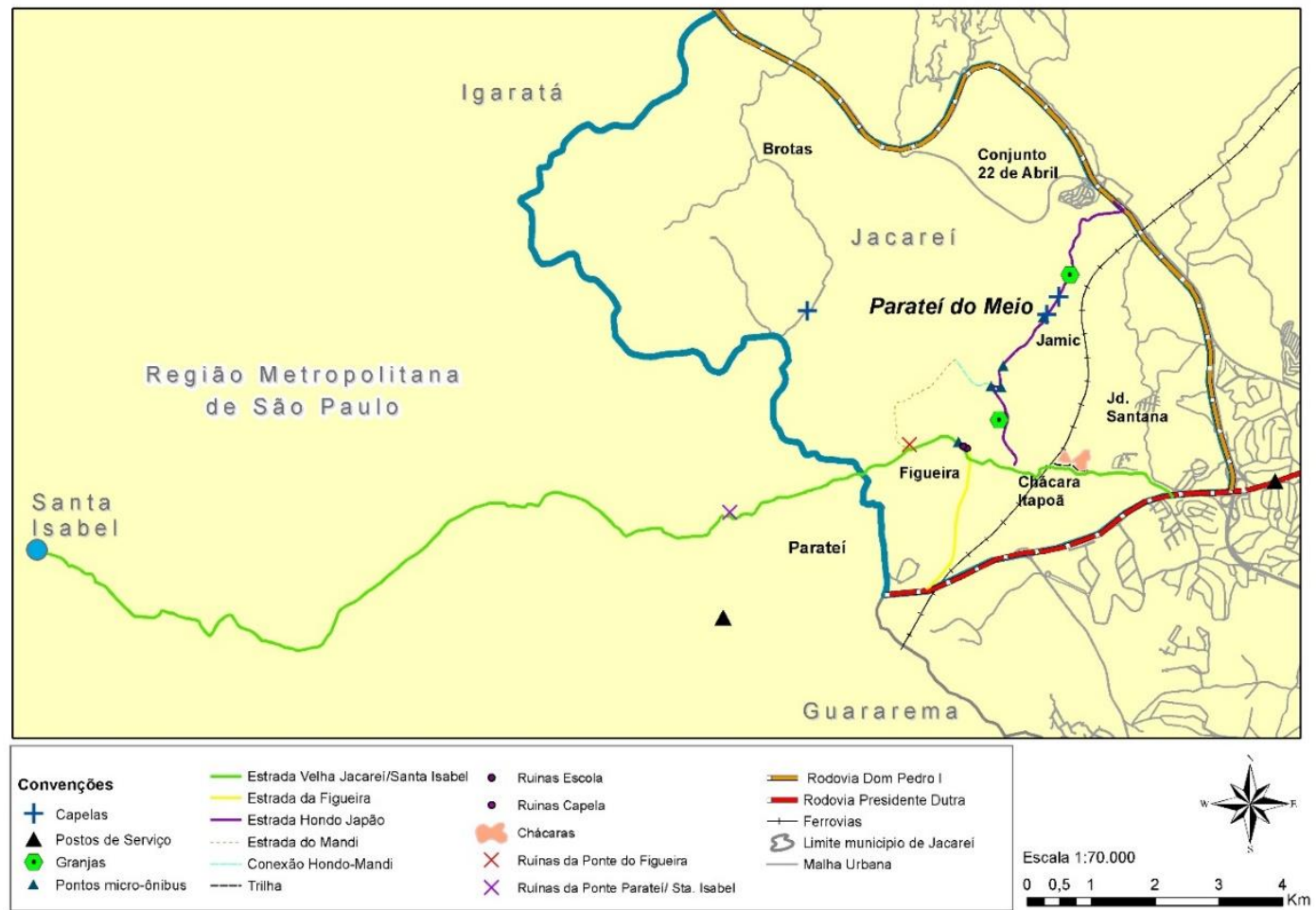

Fonte: Elaborado a partir de levantamentos em campo por Toledo, 2015.

O Bairro apresenta uma ocupação dispersa e nele não existem equipamentos sociais (posto de saúde, escola) ou espaços de uso coletivo (igreja, por exemplo). As residências se encontram em sítios ou chácaras, e algumas são de lazer. Além de relatos sobre pequenas criações de cabras, existem no bairro grandes áreas de pastagem. Nas proximidades da Rodovia Presidente Dutra muitas placas de imobiliárias fazem supor que estas áreas constituem espaços de interesse industrial, com as quais o Bairro da Figueira também faz divisa. Este seria outro fato indicador de intenções extra locais sobre o lugar, de agentes articulados por outra lógica de caráter global, não afeita aos modos de vida do lugar.

Embora o Bairro da Figueira conste em carta topográfica de 1973 do Arquivo Público do Estado e no Plano Diretor de Jacareí em 2002, este não compõe o cadastro municipal. $\mathrm{O}$ que pode contribuir para a perda gradual de sua identidade coletiva e, ainda mais, pelas ocorrências de violência relatadas.

Outra localidade da Região do Parateí do Meio é o Bairro Jardim Santana, localizado entre as vias Dom Pedro I, Rodovia Presidente Dutra e a Variante Ferroviária do Parateí. Faz limite com grande área de pastagem na direção do Bairro da Figueira.

Migrantes da região Nordeste do País residem na localidade, em razão do alto custo de moradia na cidade de Jacareí e, também, pela possibilidade de cultivos de subsistência como feijão, mandioca e verduras. Outros moradores são naturais do 
município de Guararema e ainda hoje mantêm laços familiares com moradores deste município. Eles vieram para o Bairro Jardim Santana por causa de emprego existente na cidade de Jacareí ou para trabalhar como caseiros em propriedades da localidade.

O Bairro não é atendido pelo serviço de transporte público, sendo os moradores obrigados a deslocar-se até a Rodovia Presidente Dutra para acessar o ônibus municipal ou intermunicipal, caso não utilizem outros veículos (carro, moto, bicicleta, carroça).

Igualmente ao Bairro da Figueira, a ocupação do Jardim Santana é dispersa, com predominância de fazendas, sítios ou chácaras. No Bairro encontra-se uma propriedade da Mitra Diocesana de São José dos Campos, a Capela Sant'ana, e o condomínio Pedra Branca que se mantém irregular junto à prefeitura de Jacareí. A população moradora não dispõe de posto de saúde nem escola e a segurança do Bairro pode ser avaliada pelo estado geral de temeridade dos moradores, pouca iluminação e ocorrências de violência registradas.

Na margem sul do rio Parateí, entre a Rodovia Dom Pedro I e o Bairro da Figueira encontra-se o Bairro Jamic. O nome Jamic foi atribuído ao Bairro em razão da chegada de imigrantes japoneses enviados pela Japan Management Imigration Companhy (Jamic). Há cerca de vinte e cinco anos, o Bairro deixou de ser produtor agrícola, possuindo hoje estabelecimentos para a produção de cerâmica, os quais contribuem para o parcelamento do solo e relativa concentração de edificações na Região Noroeste do município de Jacareí.

O Bairro Jamic possui quatro ruas transversais à Estrada de mesmo nome. As ruas de maior extensão possuem propriedades maiores destinadas a residências de fim de semana. As residências localizadas na margem da Estrada Jamic e em ruas menos extensas e mais estreitas parecem ser de moradores fixos. Essa é a única localidade em que se vê esgoto a céu aberto. O Bairro possui uma capela, uma sede de igreja evangélica, uma escola de ensino fundamental, produção de flores, granja de ovos e corte, comércio de queijo e um "boteco", onde se observa uma concentração de jovens aos sábados.

A escola Professora Laura Augusta de Carvalho Rosas é atendida pelo serviço de transporte público escolar, tendo recebido, recentemente, pavimentação asfáltica no trecho que a liga à Estrada Jamic. Além disso, a escola é abastecida com três caminhões pipa por semana, sendo que no geral o bairro utiliza poços para o abastecimento de água.

A Estrada Jamic faz a ligação da Estrada Hondo-Japão com a Dom Pedro I, e é o eixo principal de ligação com o Bairro da Figueira e do Bairro Jamic ao centro de Jacareí. Há grande fluxo de trabalhadores circulando de bicicleta em direção à rodovia Dom Pedro I. Aos sábados, observa-se uma frequência maior do transporte por micro-ônibus, além do transporte animal (cavalos). Existem quatro pontos de parada do transporte 
coletivo e quatro telefones públicos. Notou-se também a manifestação de jovens com idade entre 20 e 30 anos, dirigindo em alta velocidade pela Estrada Jamic, com som em alto volume. Mas, a segurança do Bairro é considerada razoável pelos moradores.

Por fim, o Bairro do Brotas localiza-se ao norte da Região Noroeste e faz divisa com o município de Igaratá. Oferece potencial para o turismo e lazer, sediando o pesqueiro Shimazan - cujo proprietário é um imigrante japonês que mora há 50 anos no Bairro, que recebe visita de pessoas provenientes dos municípios vizinhos e da capital paulista. Sítios e chácaras residenciais ou de lazer, além de granja e haras são encontrados no local. A maior parte dos moradores entrevistados morou somente no Bairro, e alguns são migrantes provenientes do interior do estado de Minas Gerais.

O acesso ao Bairro do Brotas ocorre pela Rodovia Dom Pedro I, e a partir dele é possível chegar ao Bairro Parateí em Guararema. Um dos entrevistados disse ser necessário caminhar sete quilômetros até a Rodovia Dom Pedro I para utilizar-se do ônibus municipal em direção à Região Central do município de Jacareí. O Bairro apresenta ocupação dispersa e não é considerado seguro por vários moradores. Há relatos de assalto e outras formas de violência, incluindo crimes como assassinatos, não diferente das ocorrências no Bairro da Figueira. No Bairro do Brotas também se localizam a capela Nossa Senhora do Brotas, um alambique e um campo de futebol, mas não há linha de telefone. Quanto mais próximo da divisa com Igaratá, mais espaçadas as propriedades estão entre elas. Já nas proximidades da divisa com Guararema, nota-se uma circulação mais frequente de jovens com motocicleta.

\section{DO LUGAR AO ESPAÇO QUE O ENGLOBA: a acessibilidade dos moradores}

Com base nessa descrição da Região Noroeste de Jacareí - do lugar que a organiza e dos agentes e atividades que lhes atribuem significado social e funcional -, cabe abordar a questão da acessibilidade social de seus moradores; das dinâmicas relacionais que inserem o lugar em contextos mais amplos, tornando-o não estritamente mero ponto do espaço, mas um elo de conexão local-global e, por isso, uma lente através da qual em alguma medida se vê o mundo contemporâneo, o nacional ou o regional, conforme mapa com a distribuição dos agentes (figura 9).

De acordo com Travassos e Martins (2004, p. 191), a acessibilidade social não se equipara à "mera disponibilidade de recursos em um determinado momento e lugar" $\mathrm{e}$ à acessibilidade geográfica, medida em distância e tempo de locomoção ou custo de viagem. Segundo os mesmos autores (2004) a acessibilidade social dos moradores é compreendida mais completamente se considerados os indivíduos, em suas características e necessidades, os aspectos relacionados à oferta e, ainda, à relação entre os indivíduos e os serviços ofertados

Nessa pesquisa, a acessibilidade refere-se às condições de acesso ao trabalho, a equipamentos de saúde, a educação, aos comércios e serviços e espaços de lazer. 
Respectivamente, aos residentes da Região do Parateí do Meio, a acessibilidade social remete, necessariamente, às relações de natureza urbano-rural, que se estabelecem com outros espaços da vida social.

Em relação às festas, um dos residentes do bairro da Figueira relata sobre a violência no entroncamento da Estrada da Figueira, conforme apontado por Toledo (2015, p. 97):

\begin{abstract}
...Tem uns dez anos que não faz festa. Tem cambada de vagabundo que destrói tudo. Nego já começa querer matar o outro. Festa tem assim pra promessa. A única capela que tinha acabou. Saía lá da cidade pra derrubar tudo. A fazenda derrubou. E outra, não tem mais criançada. Deu dó da igreja (informação verbal) ${ }^{5}$.
\end{abstract}

A violência, observada nos relatos de roubos, furtos e homicídios, somada ao caráter de isolamento da localidade, podem ter sido fatores determinantes para a demolição da capela e escola.

No estudo Capelas rurais de Jacareí, de autoria de Macedo (1998), a Capela Santa Cruz de Eva (figura 7) ainda se encontrava edificada. Para o autor, a comunidade fazia o uso da edificação para missas ou celebrações, e associadas à capela, aconteciam também as festas.

Outro residente, apontado por Toledo (2015, p. 107), revela que:

O padre que inventou de derrubar. [...] Só que era uma capela antiga, não era
comandada pelo padre. Só que o bairro foi ficando fraco, ficou pouca gente aí
o padre inventou de querer derrubar. [...] Depois de uma vez entraram lá,
roubaram a Igreja - sempre tem essa. O que é que tem pra roubar na igreja?
[...] Era só bagunça mesmo. A escola, como se diz, única coisa que o Sr.
prefeito diz que vai derrubar, quem é a gente pra contestar contra ele?

Essas relações urbano-rurais podem ser intermunicipais ou inter-regionais, como no caso em estudo. De fato, imaginava-se que o acesso à vida de relações sociais e aos bens e serviços necessários à sobrevivência e realização pessoal e coletiva dos moradores ocorreria no município de Jacareí, porém, muito cedo essa suposição se desfez. Baseando-se em análises iniciais das entrevistas, constata-se que a depender, sobretudo, da relativa proximidade do lugar em que é ofertado o que lhes é necessário ou das condições reais para a facilidade do deslocamento, o atendimento às necessidades é buscado em diferentes lugares ou municípios.

Figura 9 - Mapa com a distribuição dos agentes.

\footnotetext{
5 Entrevista concedida pelo Entrevistado no4 em (04/03/2014), no bairro Figueira, município de Jacareí, SP (parecer Comitê de Ética em Pesquisa 756.759/2014).
} 


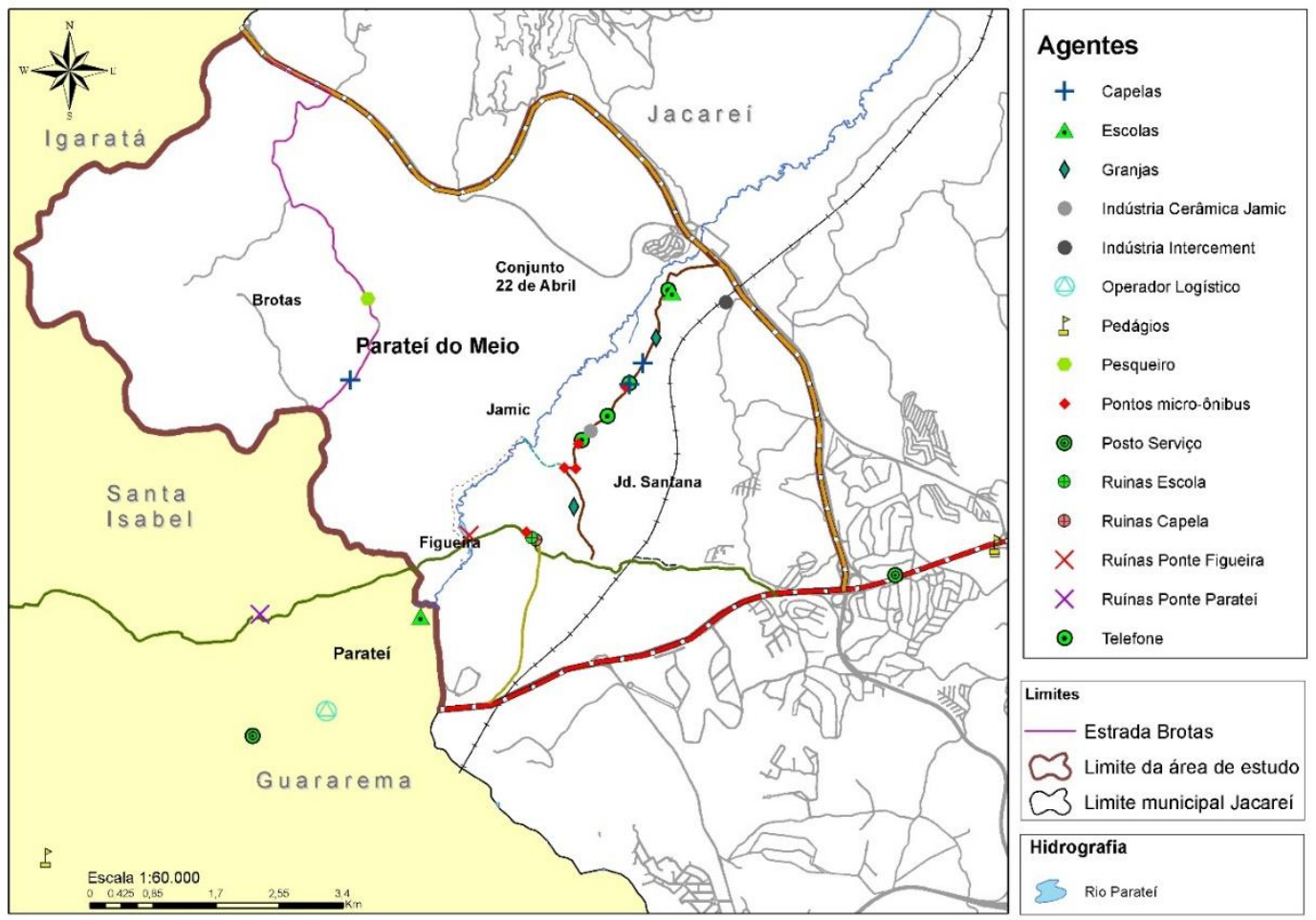

Fonte: Elaborado a partir de levantamentos em campo por Toledo, 2015.

Por exemplo, como referido adiante, o município de Guararema destaca-se em detrimento dos municípios de Jacareí e Igaratá, enquanto sede importante do que é mais acessível aos moradores do Bairro da Figueira e do Bairro do Brotas.

A figura 10 representa o potencial de acessibilidade física da estrutura urbana de Jacareí. Quanto maior a integração das vias, a coloração das mesmas tende para a cor vermelha. Em contrapartida, quanto menos integradas as vias de acesso, sua cor tende ao azul e ao violeta. Por ela, vê-se o quanto a Região Noroeste apresenta-se ainda à margem da estrutura urbana de Jacareí, distante da porção mais integrada da cidade, na imagem em tons de vermelho e laranja que coincide com o seu centro histórico e proximidades do eixo viário que leva a São José dos Campos. Ou seja, o potencial de acessibilidade física na Região Noroeste é, relativamente ao conjunto da estrutura urbana, bem menos expressivo. Os cerceamentos já apontados o tornam ainda pior. Dessa condição primeira já se infere uma dinâmica de circulação bastante comprometida.

Aliados à possibilidade do acesso físico, os meios de transporte, junto à própria renda, incidem diretamente na acessibilidade social efetiva dos moradores. Considerando o relato dos entrevistados, $50 \%$ utilizam o transporte público como primeira opção; $20 \%$ utilizam veículos automotores particulares, $10 \%$ veículo de tração animal (carroça) e outros $10 \%$ a bicicleta. Destaca-se, igualmente, a relativa maior importância do uso de motocicletas em relação aos automóveis.

Figura 10 - Mapa do potencial de acessibilidade física (mapa axial) de Jacareí, com destaque para o Parateí do Meio. 


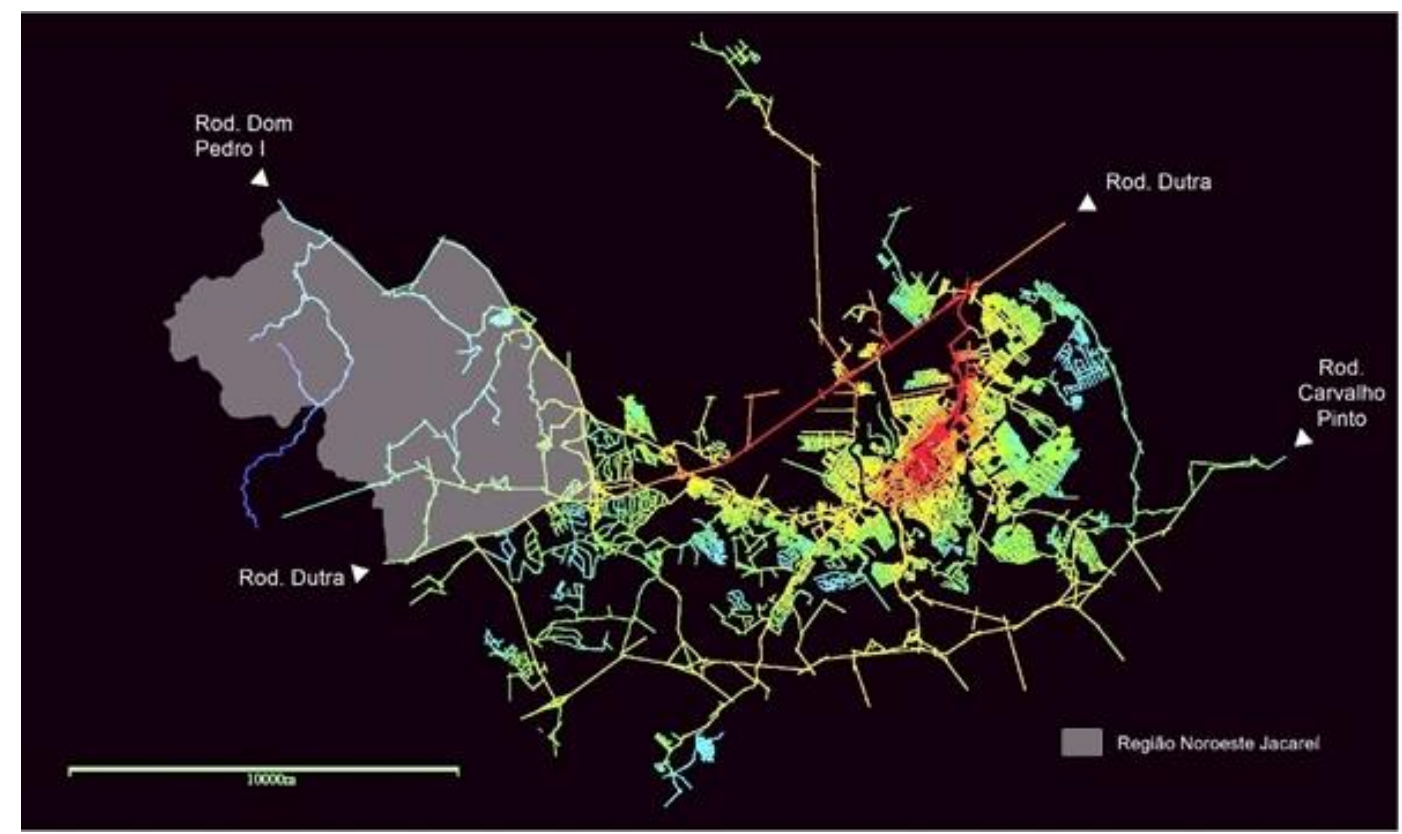

Fonte: Jacareí / Elaborado por Daniel José de Andrade, 2015.

Os trajetos das linhas de transporte público urbano que atendem a região podem ser observados na figura 12. A acessibilidade social dos moradores relaciona-se com a renda das famílias, a disponibilidade de trabalho e as condições domiciliares. Baseandose em dados do Instituto Brasileiro de Geografia e Estatística (IBGE, 2010), para 2010, constata-se uma predominância de responsáveis pelas famílias recebendo de $1 / 2$ a 2 salários mínimos e pequeno número de responsáveis com renda acima de 2 e 5 salários.

Boa parte dos entrevistados é constituída de população migrante proveniente de estados da Região Nordeste e de Minas Gerais. Pelos relatos, constata-se que muitos moradores trabalham no Bairro Parateí no município de Guararema, outros na área urbana de Jacareí e muitos na própria Região. Na figura 14 é possível observar a distribuição das pessoas segundo sua ocupação, na agricultura, pecuária, produção florestal, pesca e aquicultura, e, também, em serviços domésticos.

A situação domiciliar pode ser balizada pelos mesmos aspectos gerais característicos do meio rural em Jacareí, onde predomina: abastecimento de água na forma de poço ou nascente; esgotamento sanitário predominante por fossa séptica ou fossa rudimentar; acesso mais generalizado à energia elétrica; escolaridade predominante marcada por um elevado número de pessoas com ensino fundamental completo e médio incompleto; a maioria dos domicílios com geladeira, rádio e televisão etc. Além disso, destaca-se o uso do celular como símbolo da acessibilidade conquistada, da inclusão pelo consumo. 
Figura 12 - Linhas de transporte público que atendem o Parateí do Meio.
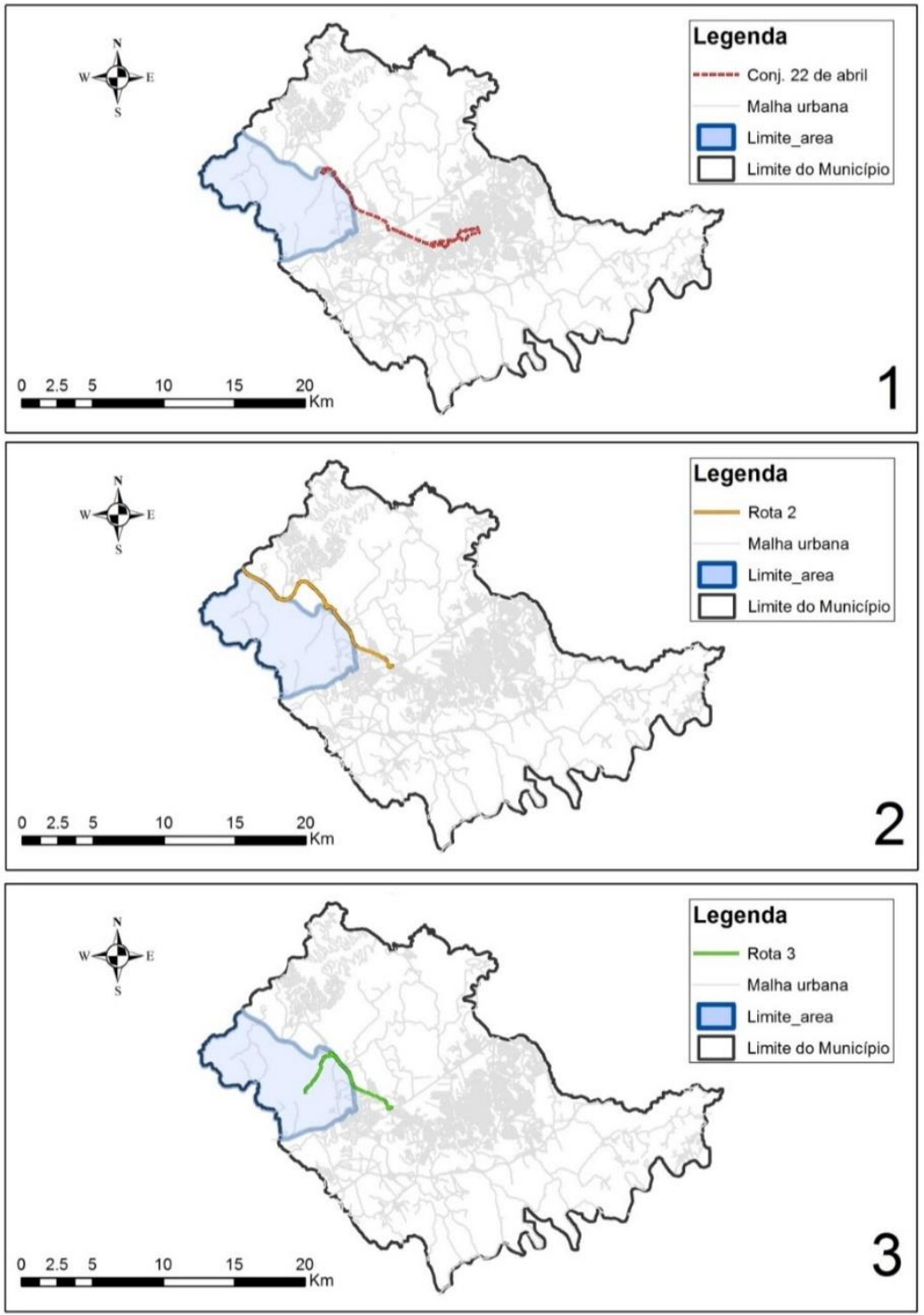

Fonte: Adaptado de Jacareí, 2012.

No Bairro Parateí, em Guararema, localiza-se a Escola Nacional Florestan Fernandes (ENFF), fundada pelo Movimento dos Trabalhadores Rurais Sem Terra (MST), onde alguns jovens da Região Noroeste de Jacareí estudam informática, línguas e outros assuntos. Segundo uma moradora do bairro, "os projetos deles são muito bons, é muita cultura num lugar só". Continuando a moradora diz que "pessoas de vários países vão para a Escola Nacional estudar". E nesse mesmo bairro, existe também uma igreja que é bastante frequentada por moradores da Região.

Assim sendo, o município de Guararema exerce um importante papel para os residentes na margem norte do Rio Parateí, isolados pela ponte levada pelas chuvas nos anos de 1980. Destaca-se em detrimento de Jacareí ou, Igaratá, como local mais acessível aos moradores do Figueira e do Brotas". 
Figura 14 - Pessoal ocupado.

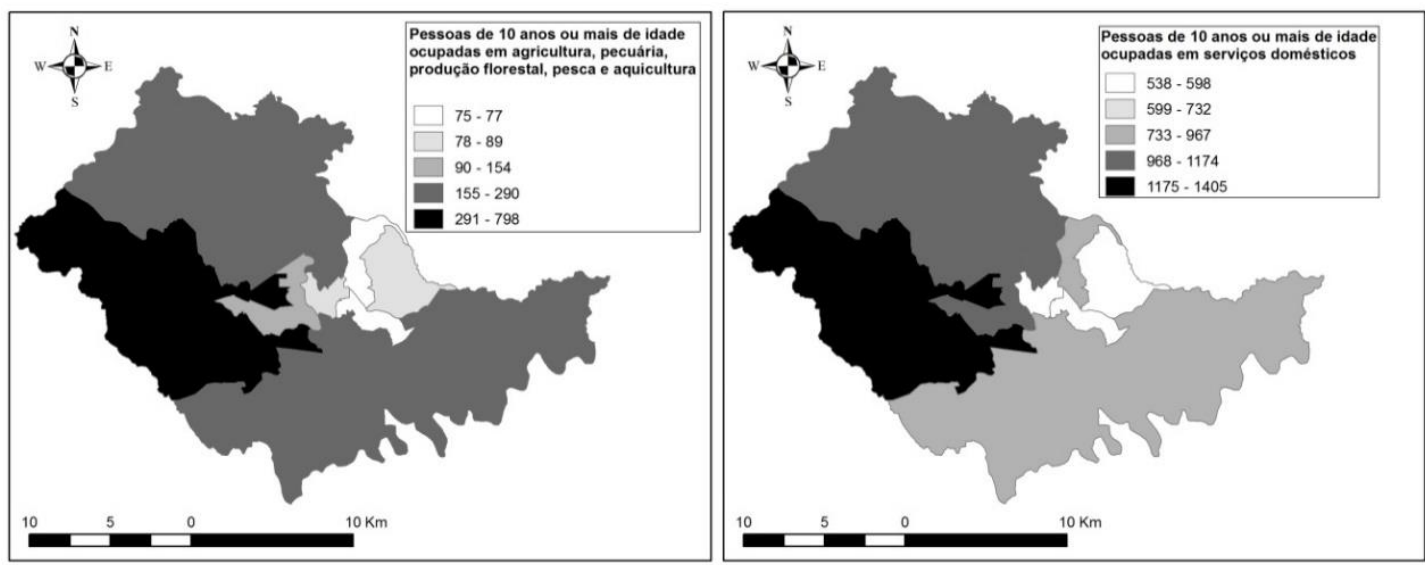

Fonte: IBGE, 2010.

Nos relatos, nota-se que a Região Central de Jacareí é talvez o principal lugar de referência para o acesso a serviços de saúde, comerciais, bancários, a agências de transporte e distribuição de correspondências e administrativos etc. No que se refere ao acesso às Unidades Básicas de Saúde, moradores do Bairro do Brotas dirigem-se ao município de Igaratá e dos Bairros Jamic e Jardim Santana ao Bairro Igarapés no município de Jacareí.

Quando perguntados a respeito da segurança nestes Bairros, boa parte dos moradores considera que o respectivo Bairro não é seguro, pela ocorrência de assaltos, sequestros-relâmpago, roubos, "desova" de carros roubados e até assassinatos. $O$ retrato da insegurança fez-se presente na grande quantidade de cães de guarda nos sítios e chácaras e, até mesmo, no receio de alguns moradores de concederem as entrevistas.

\section{CONSIDERAÇÕES FINAIS: através do lugar periurbano de Jacareí}

Com base na imagem dos espaços diferenciados que organizam o Parateí do Meio, dos cerceamentos à circulação e condições da acessibilidade social de seus moradores, algumas considerações serão ordenadas para ressaltar alguns pontos conclusivos principais que instigam a futuro aprofundamento e ampliação da discussão sobre lugares mantidos à margem das preocupações que orientam a proposição de políticas públicas de caráter socioterritorial.

Um desses pontos trata da influência de nexos globais incidentes em localidades periurbanas ou, originalmente, de características mais rurais. Estes nexos globais podem ser representados não só pelas racionalidades hegemônicas de empresas atuantes em circuitos econômicos transnacionais, bem como de agentes de certos segmentos sociais, oriundos do mundo urbano, com suas lógicas culturais próprias, que investem ou se instalam nessas localidades, e/ou delas se apropriam para fins diversos. 
A principal questão aí envolvida é a que advém da convivência e/ou do embate de racionalidades locais e extralocais, passíveis de geração de conflitos e desorganização do espaço local em razão de interesses alheios ao modo de vida local, desinteressados, portanto (salvo exceções) do diálogo mais profícuo com as populações locais, suas culturas e narrativas próprias. No estudo em foco, a localização imediata (da região do Parateí) a duas importantes rodovias e sua condição interna de cerceamentos de caminhos e, por isso, de relativo isolamento, termina favorecendo a apropriação indevida do local para a prática de violências por agentes forâneos.

A questão das relações entre acessibilidade física e social torna-se um ponto para debates ampliados. Nesse sentido, a acessibilidade social poderá ser reavaliada, de um lado, pelas desatenções do poder público e pelo descaso das políticas públicas no que se refere aos preceitos constitucionais, e de outro lado, pelos acordos ou desacordos entre moradores e agentes extralocais, e entre os próprios moradores relativamente ao que lhes é importante e necessário, mas também, pela voz destes e sua real consciência dos direitos de cidadania que lhes cabem.

As relações entre populações locais, agentes diversos da sociedade civil e o poder público e as relações entre as municipalidades e demais instâncias do poder público estão na base do tratamento da questão da acessibilidade social dos moradores da Região do Parateí do Meio ou de qualquer outro lugar com características similares.

O ordenamento territorial é previsto constitucionalmente, assim como o município em seu todo deve ser considerado no Plano Diretor. O acesso ao que se supõe ser de direito do cidadão independente do lugar de vida ou habitação é, portanto, uma das questões nevrálgicas do planejamento (MOURA FILHO, 2010). Mas por que é tão difícil que as condições de acessibilidade social sejam efetivamente respeitadas e qualificadas?

De um lado, temos a existência de um sistema normativo aparentemente demonstrativo da ação do poder público e, de outro, a condição de enorme distância social - embora tão próximo ao mundo urbano -, não só do lugar periurbano constituído no Parateí do Meio, mas de tantos outros lugares, na Região ou no País, que se pode entrever a partir desse pequeno lugar no município de Jacareí.

Toledo, Souza e Gomes (2014) observam que com as populações periurbanas ou rurais à margem das políticas públicas, caminhos alternativos e soluções próprias são buscados na Região do Parateí do Meio e demais localidades situadas no "vácuo" dos interesses políticos e econômicos globais. O que nos leva a ponderar sobre as imensas contradições e defasagens sociais não consideradas por ocasião da formulação de políticas públicas, em desrespeito, portanto, aos direitos de cidadania dos habitantes que vivem em meio rural, no Vale do Parateí, nos bairros que o compõem, ou em qualquer outra localidade rural da Região ou do País.

A desagregação do tecido socioespacial do território de Jacareí e a ineficiência do 
poder público e da ação coletiva estão na base de um processo histórico que tem criado e agravado a condição de iniquidade social. A violência é uma das evidências de códigos éticos, talvez a mais desesperada, da violência estrutural maior do sistema social e econômico, e o antídoto a essa negatividade sistêmica, tende a ser, necessariamente, o fortalecimento de laços de interdependência ou formas de solidariedade social em vista de políticas públicas e processos de desenvolvimento e planejamento socialmente construídos.

A esse respeito, considera-se que tanto maior a insuficiência do lugar e das condições reais de seus moradores para a realização da vida pessoal e social, mais intensas precisam ser suas interdependências. Nessa circunstância, depende-se mais uns dos outros. Depende-se mais da força gerada pelas associações e/ou por processos de cooperação e realização social conjunta. E por isso, depende-se mais das dinâmicas relacionais com outros lugares e da consciência que se tem sobre o próprio mundo contemporâneo.

Nesse contexto, constituir uma visão de conjunto de regiões e lugares, em toda sua diversidade, é priorização do método geográfico, em vista de ultrapassar os localismos e graduar a compreensão do lugar em que vivemos por meio de nexos mais unitários. Em vista de partir do lugar mas enxergar o mundo através do lugar. $\mathrm{O}$ planejamento não deve ser pensado pontualmente, e, portanto, as análises de conjunto são fundamentais, ainda que a partir de dimensões socioespaciais diminutas como são os bairros periurbanos ou rurais do Parateí do Meio.

No caso, o único compromisso possível que parece poder engajar o trabalho de reflexão teórica e metodológica realizado na universidade - por via da participação no debate social e de sua permanente construção e ampliação - é o de fazer conduzir a análise da realidade ao pensar decisivo sobre a sua transformação mediante a perspectiva de um planejamento menos pontual e exclusivista e, por isso, mais socializante e abrangente de todos os cidadãos e todos os lugares, do espaço de todos.

\section{REFERÊNCIAS}

AB'SABER, Aziz Nacib. Paisagens e problemas rurais da região de Santa Isabel. Boletim Paulista de Geografia, n.10, p. 45-70, 1951.

ALVES, Xandu. Projeto da Chery, núcleo de autopeças de Jacareí deve estar concluído em dois anos com investimento de US 700 milhões. O Vale, 2015. Disponível em: http://www.ovale.com.br/novo-polo-abre-5-000-empregos-1.588495. Acesso em: 26 maio 2015.

CODIVAP CONSÓRCIO DE DESENVOLVIMENTO INTEGRADO DO VALE DO PARAÍBA, SERRA DA MANTIQUEIRA E LITORAL NORTE. Caracterização e avaliação dos conhecimentos existentes sobre a região do Vale do Paraíba e diagnósticos resultantes. Pindamonhangaba, SP, 1972. 328 p.

INSTITUTO BRASILEIRO DE GEOGRAFIA E ESTATÍSTICA - IBGE. Censo demográfico de 2010. 2010. Disponível em: 
www.censo2010.ibge.gov.br/sinopseporsetores. Acesso em: 15 abr. 2014.

JACAREÍ. Prefeitura - PMJ. Plano Diretor de Ordenamento Territorial. Jacareí: PMJ, Secretaria de Planejamento, 2012.112 p.

KANAZAWA, Julia Naomi. Os (i)migrantes japoneses e seus descendentes em Jacareí, 1927-1951: contexto, trajetória e cotidiano. 2008. Dissertação (Mestrado) Universidade de São Paulo, São Paulo, 2008. Disponível em: http://www.teses.usp.br/teses/disponiveis/8/8138/tde-02042009-092501/. Acesso em: 25 nov. 2014.

MACEDO, Nubia dos Santos. Capelas rurais de Jacareí. 1998. 210f. Trabalho de graduação (Arquitetura e Urbanismo) - Universidade do Vale do Paraíba, São José dos Campos, 1998.

MAGNANI, José Guilherme Cantor. De perto e de dentro: notas para uma etnografia urbana. En linea. São Paulo: Rev. bras. Ci. Soc., v. 17, n. 49, 2002. Disponível em: http://www.scielo.br/scielo.php?script=sci_arttext\&pid=S0102-

$69092002000200002 \&$ Ing=en\&nrm=iso. Acesso em: 10 out. 2014.

MOURA FILHO, José Luiz de. A relação urbano/rural no Estatuto da Cidade. Revista Eletrônica do Curso de Direito, v. 5, n. 3, p. 1981-3694, 2010. Disponível em: $<$ http://cascavel.ufsm.br/revistas/ojs-

2.2.2/index.php/revistadireito/article/view/7056/4269>. Acesso em 18 jun. 2014.

MÜLLER, Nice Lecocq. O fato urbano na bacia do Rio Paraíba estado de São Paulo. Rio de Janeiro, RJ: IBGE, Instituto Brasileiro de Geografia, 1969. 375 p.

RANDOLPH, Rainer; SOUTHERN, Barbra Candice. Expansão metropolitana e transformação das interfaces entre cidade, campo e região. São Paulo: Mas Limonad. 2011. 337 p.

SANTOS, Milton. Por uma outra globalização: do pensamento único à consciência universal. Rio de Janeiro, RJ: Record, 2000. 174 p.

SANTOS, Milton; SILVEIRA, Maria Laura Silveira. O Brasil: território e sociedade no início do século XXI. Rio de Janeiro: Record, 2001. 471 p.

SAPUCAHY, Mário Lúcio. 1822: um botânico europeu em viagem pelo Vale do Paraíba. São José dos Campos: Mls, 1998. 108 p.

SILVA NETO, Manoel Lemes da. A interação técnico-econômica do território paulista. In: ENCONTRO BRASILEIRO DE ESTUDOS REGIONAIS E URBANOS, 2., 2002.

Anais..., São Paulo: Associação Brasileira de Estudos Regionais, 2002.

TOLEDO, André Luiz de. Precárias condições de circulação. 2013a. (1 fot.): color.

TOLEDO, André Luiz de. Estrada interrompida por Condomínio. 2013b. (1 fot.): color.

TOLEDO, André Luiz de. Estrada da Figueira. 2014a. (1 fot.): color.

TOLEDO, André Luiz de. Ruínas - escola e capela. 2014b. (1 fot.): color.

TOLEDO, André Luiz de; SOUZA, Adriane a. Moreira de; GOMES, Cilene. Circulação 
e dinâmicas urbano-rurais: questões de planejamento territorial à luz do estudo de uma localidade rural a noroeste de Jacareí, SP. In: SEMINÁRIO NACIONAL DE PLANEJAMENTO E DESENVOLVIMENTO. 2, 2014. Florianópolis. Anais.... Florianópolis: UDESC, 2014. 16p. Disponível em: <http://www.eventos.ct.utfpr.edu.br/anais/snpd/pdf/snpd2014/602.pdf>. Acesso em: 26 fev. 2019.

TOLEDO, André Luiz de. Circulação, acessibilidade social e questões do planejamento territorial / análise da dinâmica socioespacial urbano-rural do Bairro do Parateí do meio em Jacareí, SP. São José dos Campos, SP, 2015. 185 f. Dissertação (Mestrado em Planejamento Urbano e Regional) - Universidade do Vale do Paraíba, São José dos Campos, 2015.

TRAVASSOS, Claudia; MARTINS, Mônica. Uma revisão sobre os conceitos de acesso e utilização de serviços de saúde. Cad. Saúde Pública, v. 20, supl. 2, p. 190-198, 2004. 